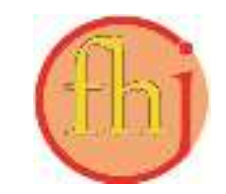

Faletehan Health Journal, 7 (3) (2020) 119-123

www. journal.Ippm-stikesfa.ac.id/ojs/index.php/FHJ

ISSN 2088-673X | e-ISSN 2597-8667

\title{
Kepemilikan Jamban Sehat Pada Masyarakat
}

\author{
Mukhlasin $^{1 *}$, Encep Nugraha Solihudin ${ }^{1}$ \\ ${ }^{1}$ Fakultas IImu Kesehatan Universitas Faletehan, Serang, Indonesia \\ *Corresponding Author: sintong212@gmail.com
}

\begin{abstract}
Abstrak
Penggunaan jamban leher angsa pada masyarakat di desa Walikukun Kecamatan Carenang Kabupaten Serang sebanyak Desa Walikukun 50,36\%, pengguna. Tujuan Penelitian ini adalah mengetahui ketersediaan air bersih, ketersediaan lahan, dan pendapatan yang berhubungan dengan kepemilikan jamban pada masyarakat di Desa Walikukun Kecamatan Carenang Kabupaten Serang Tahun 2020. Metode dalam penelitian ini menggunakan desain crossectional. Jumlah Responden pada penelitian ini sebanyak 87 responden. Teknik pengambilan sampel dengan menggunakan simple random sampling dengan analisis bivariat menggunakan Chi square test. Hasil penelitian menunjukkan bahwa semua variabel berhubungan dengan kepemilikan jamban di Desa Walikukun Kecamatan Carenang; ketersediaan air bersih ( $\mathrm{pv}=0,000 ; O R=117,8)$, ketersediaan lahan $(\mathrm{pv}=0,000)$, variabel pendapatan $(p v=0,000)$. Penelitian ini menyimpulkan bahwa sebagian besar masyarakat $(68,8 \%)$ tidak memiliki jamban.

Kata Kunci: Air Bersih, Lahan, Kepemilikan Jamban, Pendapatan
\end{abstract}

\section{Healthy Latrine Ownership in Community}

\begin{abstract}
The use of gooseneck latrines among the community of Walikukun Village, Carenang District, Serang Regency achieves $50.36 \%$, users. The purpose of this study is to determine the availability of clean water, land availability, and income associated with latrine ownership among the community of Walikukun Village, Carenang District, Serang Regency in 2020. The method of this study is cross-sectional design. The number of respondents in this study are 87 respondents. The sampling technique used simple random sampling and the bivariate analysis used Chi square test. The results showed that all variables were related to latrine ownership in Walikukun Village, Carenang District, Serang Regency; availability of clean water ( $p$ value 0.000; OR 117.818), land availability variable ( $p$ value $0.000)$, income variable ( $p$ value 0.000). The conclusion of this study is that some people (68.8\%) did not have a toilet. Keywords: Latrines, Clean Water, Land, Income
\end{abstract}




\section{Pendahuluan}

Sanitasi merupakan salah satu upaya untuk mengatasi beberapa faktor lingkungan fisik yang dibutuhkan makhluk-makhluk utama yang mempunyai dampak merusak bagi perkembangan fisik, kesehatan dan kesehatan dan kelangsungan hidup (Mukhlasin, Fitri, \& Elengoe, 2020).

Istilah sanitasi juga mengacu kepada pemeliharaan kondisi higienis melalui upaya penyediaan sarana dan pelayanan pembuangan limbah kotoran manusia seperti urine dan faeces. Sanitasi berhubungan dengan kesehatan lingkungan yang mempengaruhi derajat kesehatan masyarakat. Buruknya kondisi sanitasi akan berdampak negative di banyak aspek kehidupan, mulai dari turunnya kualias lingkungan hidup masyarakat, tercemarnya sumber air minum bagi masyarakat, meningkatnya jumlah kejadian diare dan muncunya beberapa penyakit (Zenni, 2020).

Kepemilikan jamban termasuk kedalam sanitasi dasar maka seharusnya semua orang sudah memiliki jamban, jika kepemilikan jamban dimasyarakat rendah akan semakin tinggi yang melakukan Buang Air Besar Sembarangan (BABS), dimana hal tersebut dapat mengganggu kesehatan serta dapat menimbulkan pencemaran lingkungan.Berdasarkan konsep dan definisi MDGs, rumah tangga memiliki akses sanitasi layak apabila fasilitas sanitasi yang digunakan memenuhi syarat kesehatan, antara lain dilengkapi dengan jenis kloset leher angsa atau plengsengan dengan tutup dan memiliki tempat pembuangan akhir tinja tangki (septic tank) atau Sistem Pengolahan Air Limbah (SPAL), dan merupakan fasilitas buang air besar yang digunakan sendiri atau bersama (Kemenkes, 2017).

Berdasarkan data STBM smart akses kepemilikan jamban Provinsi Banten Tahun 2019 sebesar $72,12 \%$ dimana Kota Serang mengalami peningkatan akses jamban yaitu $72,80 \%$ dan Kabupaten Serang tertinggal dengan cakupan kepemilikan jamban 64,91\% (Dinkes Banten, 2016).

Berdasarkan data Dinas Kesehatan Kabupaten Serang Tahun 2018 dari 31 Puskesmas yang ada di Kabupaten Serang terdapat tiga puskesmas dengan persentase cakupan kepemilikan jamban terendah yaitu Puskesmas Carenang 43,1\%, Puskesmas Pamatang 48,4\% dan Puskemas Mancak 48,5\% (Dinkes Kabupaten Serang, 2018).
Berdasarkan data yang diperoleh dari Puskesmas Carenang tahun 2019 dari8 Desa yang ada di Kecamatan Carenang terdapat 3 Desa dengan presentase keluarga yang mempunyai akses atau menggunakan jamban sehat terendah yaitu Desa Walikukun 50,36\%, Desa Teras 60,80\%, Desa Mekarsari 73,42\% (Dinkes Kabupaten Serang, 2018).

Penelitian ini bertujuan untuk mengetahui ketersediaan air bersih, ketersediaan lahan dan pendapatan yang berhubungan dengan kepemilikan jamban pada masyarakat di Desa Walikukun Kecamatan Carenang Kabupaten Serang Banten.

\section{Metode Penelitian}

Penelitian ini menggunakan metode kuantitatif dengan desain cross-sectional. Penelitian ini dilakukan di Desa Walilikukun Kecamatan Carenang Kabupaten Serang, pada bulan April-Juli 2020. Populasi penelitian ini adalah kepala rumah tangga sebanyak 1.544 orang. Perhitungan besar sampel yang digunakan adalah uji hipotesis untuk dua proporsi populasi. Berdasarkan hasil perhitungan diperoleh jumlah sampel minimal sebanyak 87 responden, teknik pengambilan sampel menggunakan sample random sampling, dimana sampel dibagi berdasarkan RW kemudian diperoleh proporsi sesuai perhitungan dan kemudian dari setiap KK. Pada penelitian pengumpulan data primer dilakukan dengan wawancara tidak langsung terhadap responden dengan instrument kuesioner dalam bentuk google form.Pengumpulan data sekunder dilakukan dengan melihat data dari Puskesmas Carenang.Analisa data dilakukan secara univariat dan bivariat. Analisa univariat dilakukan untuk memperoleh gambaran data mengenai gambaran tiap variabel dalam penelitian. Analisa bivariat dilakukan untuk mengetahui hubungan yang signifikan antara variabel independen dan dependen dengan menggunakan Uji Kai Kuadrat (Chi Square Test).

\section{Hasil dan Pembahasan}

Dari hasil penelitian yang dianalisis pada tabel 1 sebagian besar 68,8\% responden tidak memiliki jamban, sebagian besar 56,3 respoden tidak tersedia air bersih, sebagian besar $67,8 \%$ responden tidak tersedia lahan dan sebagian besar $85,1 \%$ responden pendapatan rendah. 
Faletehan Health Journal, 7 (3) (2020) 119-123

www. journal.Ippm-stikesfa.ac.id/ojs/index.php/FHJ

ISSN 2088-673X | 2597-8667

Tabel 1. Gambaran Kepemilikan Jamban, Ketersediaan Air Bersih, Ketersediaan Lahan dan Pendapatan

\begin{tabular}{lcc}
\hline \multicolumn{1}{c}{ Variabel } & N & \% \\
\hline Kepemilikan Jamban & & \\
\hline Tidak Memiliki & 59 & 67,8 \\
\hline Memiliki & 28 & 32,2 \\
\hline Ketersediaan Air Bersih & & \\
\hline$\quad$ Tidak Tersedia & 49 & 56,3 \\
\hline$\quad$ Tersedia & 38 & 43,7 \\
\hline Ketersediaan Lahan & & \\
\hline$\quad$ Tidak Tersedia & 59 & 67,8 \\
\hline$\quad$ Tersedia & 28 & 32,2 \\
\hline Pendapatan & & \\
\hline$\quad$ Rendah & 74 & 85,1 \\
\hline Tinggi & 13 & 14,9 \\
\hline
\end{tabular}

\section{Kepemilikan Jamban}

Kepemilikan jamban dalam penelitian ini adalah sarana atau bangunan yang dipergunakan oleh keluarga untuk membuang tinja atau kotoran manusia dan lazim disebut kakus/WC yang memenuhi syarat kesehatan adalah salah satunya dengan menggunakan jamban leher angsa dan memiliki saluran pembuangan kotoran berupa septictank.

Berdasarkan hasil penelitian diketahui bahwa keluarga yang tidak memiliki jamban lebih banyak yaitu $59(68,8 \%)$ keluarga, dibandingkan dengan keluarga yang memiliki jamban yaitu 28 $(32,2 \%)$ keluarga. Penelitian ini sejalan dengan hasil penelitian yang dilakukan oleh Arlin, Sudirman, \& Nurafni (2018) di Desa TA Aniuge Kecamatan Tomini Kabupaten Parigi Moutong, didapatkan bahwa sebagian besar responden tidak memiliki jamban sebanyak 53 (70,3\%)(Arlin, Sudirman, 2018).

Kepemilikan jamban yang masih rendah dapat menimbulkan berbagai dampak pada lingkungan dan kesehatan masyarakat itu sendiri, jika masyarakat memiliki perilaku buang air besar tidak pada jamban atau faces dibuang langsung ke sungai atau kebun dapat menyebabkan pemandangan yang tidak sopan, menimbulkan bau yang tidak sedap dan berdampak pada kesehatan seperti menyebabkan penyakit diare.

\section{Ketersediaan Air Bersih dengan Kepemilikan Jamban}

Berdasarkan hasil penelitian menunjukan ada hubungan yang signifikan antara ketersediaan air bersih dengan kepemilikan jamban pada masyarakat di Desa Walikukun Kecamatan Carenang Kabupaten Serang.Penelitian ini sejalan dengan penelitian sebelumnya yang menyatakan ada hubungan yang bermakna antara ketersediaan air bersih dengan kepemilikan jamban (Fitri, E. W., \& Putri, 2016).

Ketersediaan air bersih merupakan faktor pemungkin untuk perilaku sehat, karena dengan tersedianya air bersih akan lebih memudahkan anggota keluarga untuk menjaga kebersihan diri, ketersediaan air bersih juga sangat berkaitan dengan kegiatan yang dilakukan dijamban untuk membilas dan membersihkan kotoran dijamban. Dari hasil penelitian terlihat bahwa ketersediaan air bersih sangat berpengaruh terhadap kepemilikan jamban, hal tersebut terlihat bahwa kepemilikan jamban mayoritas didominasi oleh keluarga yang memiliki air bersih. Hal ini disebakan karena letak Desa Walikukun terletak didekat sungai dan sawah sehingga memunculkan kebiasaan masyarakat untuk memperoleh air dari sungai dan kolam tanpa plester.

\section{Ketersediaan Lahan dengan Kepemilikan Jamban}

Berdasarkan hasil penelitian menunjukan bahwa ada hubungan yang signifikan antara ketersediaan lahan dengan kepemilikan jamban pada masyarakat di Desa Walikukun Kecamatan Carenang Kabupaten Serang.Penelitian ini sejalan dengan penelitian sebulumnya yang menyatakan ada hubungan yang signifikan antara ketersediaan lahan dengan kepemilikan jamban(Arlin, Sudirman, 2018).

Kepemilikan lahan sangat berpengaruh kepada kepemilikan jamban karena dengan memiliki lahan sendiri seseorang akan bebas membangun apa saja yang ada diatas lahannya tanpa takut ada yang menghalangi, begitu juga dengan membangun jamban seseorang yang memilki jamban akan bebas untuk membangun jamban secara keseluruhan, besar atau kecilnya tergantung keinginan karena didukung dengan ketersediaan lahan(Arlin, Sudirman, 2018).

Dari hasil penelitian terlihat bahwa ketersediaan lahan sangat berpengaruh terhadap kepemilikan jamban.Hal itu disebabkan karena sebagian besar masyarakat di Desa Walikukun tidak memiliki lahan cukup untuk membuat jamban dan septictank 
Tabel 2. Hubungan Antar Variabel Penelitian ( $\mathrm{n}=87$ )

\begin{tabular}{|c|c|c|c|c|c|c|}
\hline \multirow{3}{*}{ Variabel } & \multicolumn{4}{|c|}{ Ketersediaan Jamban } & \multirow{3}{*}{ Jumlah } & \multirow{3}{*}{ Pvalue } \\
\hline & \multicolumn{2}{|c|}{ Tidak Memiliki } & \multicolumn{2}{|c|}{ Memiliki } & & \\
\hline & $\mathbf{N}$ & $\%$ & $\mathbf{N}$ & $\%$ & & \\
\hline \multicolumn{7}{|c|}{ Ketersediaan Air Bersih } \\
\hline Tidak Tersedia & 48 & 98 & 1 & 2 & 49 & \multirow[t]{2}{*}{0,000} \\
\hline Tersedia & 11 & 28,9 & 27 & 71,1 & 38 & \\
\hline \multicolumn{7}{|l|}{ Ketersediaan Lahan } \\
\hline Tidak Tersedia & 59 & 100 & 0 & 0 & 59 & \multirow[t]{2}{*}{0,000} \\
\hline Tersedia & 0 & 0 & 28 & 100 & 28 & \\
\hline \multicolumn{7}{|l|}{ Pendapatan } \\
\hline Rendah & 59 & 79,7 & 15 & 20,3 & 74 & \multirow[t]{2}{*}{0,000} \\
\hline Tinggi & 0 & 0 & 13 & 100 & 13 & \\
\hline
\end{tabular}

\section{Pendapatan dengan Ketersediaan Jamban}

Berdasarkan hasil penelitian menunjukan bahwa ada hubungan yang signifikan antara pendapatan dengan kepemilikan jamban pada masyarakat di Desa Walikukun Kecamatan Carenang Kabupaten Serang. Penelitian ini sejalan dengan penelitian sebelumnya yang menyatakan bawah ada hubungan yang bermakna antara pendapatan dengan kepemilikan jamban(Kafit, 2013).

Dari hasil penelitian ini dapat dilihat sebagian besar keluarga di Desa Walikukun berpendapatan rendah yaitu Rp. 500.000 - Rp. 1.000.000 perbulan.Hal ini disebabkan pendapatan masyarakat di Desa Walikukun dipengaruhi oleh beberapa faktor seperti tingkat pendidikan dan pekerjaan.Untuk rata-rata pekerjaan pada masyarakat di Desa Walikukun adalah sebagai petani sehingga membuat pendapatan tidak menentu setiap bulannya.

Tingkat pendapatan seseorang untuk memenuhi kebutuhan hidup atau status ekonomi yang baik akan berpengaruh pada fasilitas yang diperoleh. Apabila tingkat pendapat baik maka, fasilitas kesehatan mereka khususnya didalam rumahnya akan terjamin, misalnya dalam penyediaan jamban keluarga. Rendahnya pendapatan merupakan rintangan bagi kalangan tifak mampu memenuhi fasilitas kesehatan sesuai kebutuhan.Dari hasil penelitian terlihat bahwa pendapatan sangat berpengaruh terhadap kepemilikan jamban. Hal ini disebabkan karena sebagian besar masyarakat di Desa Walikukun memiliki pendapatan yang cukup rendah. Mahalnya bahan bangunan membuat masyarakat enggan berfikir untuk membuat jamban dan septictank.

\section{Simpulan}

Penelitian ini dilaksanakan di Desa Walikukun Kecamatan Carenang dengan jumlah responden sebanyak 87 responden. Berdasarkan penelitian dapat disimpulkan bahwa sebagian besar $(68,8 \%)$ keluarga tidak memiliki jamban dan terdapat hubungan yang signifikan antara keterserdiaan air bersih, ketersediaan lahan, dan pendapatan dengan kepemilikan jamban di Desa Walikukun Kecamatan Carenang Kabupaten Serang.

\section{Referensi}

Arlin, Sudirman, N. (2018). Fakto-Faktor Yang Behubungan Dengan Kepemilikan Jamban di Desa Ta Anuge Kecamatan Tomini Kabupaten Parigi Moutong.

Dinkes, B. (2016). Profil Dinas Kesehatan Provinsi Banten.

Fitri, E. W., \& Putri, E. G. (2016). Analis FaktorFaktor Yang Berhubungan Dengan Kepemilikan Jamban di Desa Baru Semereh Kecamatan Sitinjau Laut Kabupaten Kerinci. Jurnal Kesehatan Medika Vol 7(1).

Kafit. (2013). Faktor-Faktor Yang Berhubungan Terhadap Kepemilikan Jamban Sehat di Desa Sungai Rambai Kecamatan Tebo Ulu Kabupaten Tebo. Riset Informas Kesehatan Vol 7, No.1.

Kemenkes, R. (2017). Profil Kesehatan Republik Indonesia Tahun 2017. Banten: 2016.

Mukhlasin, Fitri, M., \& Elengoe, A. (2020). Sanitation of Ro-Ro vessel at the port of ferry branch Merak Banten - -. Enfermería Clínica, 30, 213-215. https://doi.org/10.1016/j.enfcli.2019.11.057

Serang, D. K. (2018). Profil Dinas Kesehatan 
Faletehan Health Journal, 7 (3) (2020) 119-123 www. journal.Ippm-stikesfa.ac.id/ojs/index.php/FHJ ISSN 2088-673X | 2597-8667

Kabupaten Serang. Serang.

Zenni, S. (2020). Sanitasi Lingkungan Penyebab Diare Pada Anak (p. 1). p. 1. Retrieved from https://www.kompasiana.com/zennisinaga37 44/5f53bbadd541df53bd4a0ba2/sanitasilingkungan-penyebab-diare-pada-anak 